\title{
Representations of Girlhood and Girl Stereotypes in Victoria Aveyards' The Red Queen Collection
}

\author{
Masoumeh Soltani ${ }^{1}$, Laleh Atashi ${ }^{2}$ \\ Shiraz University, Iran \\ e-mail: masumesoltani1993@gmail.com¹, laleh.atashi@shirazu.ac.ir²
}

\begin{abstract}
Given the fact that girlhood is a new area of investigation which intriguingly demonstrates various ways through which girlhood is structured by different social and cultural codes, the authors intended to examine girl characters in The Red Queen collection as it was the New York Times Best Selling series. This investigation revealed the ways cultural and social norms prescribe specific gender roles and shape different versions of girl characters in this series. To find girl stereotypes in the collection, such girlhood theories as Girl Power, Reviving Ophelia, \#LIKEAGIRL, Girl Effect and Girl Up had been taken into consideration. Various depictions of girlhood are represented through characters who have different ethnic and social backgrounds. This implies that the formation of girl identity has a lot to do with social, economic, political and cultural structures. However, identity formation is an ongoing process and can change in the course of an individual's self-development.
\end{abstract}

Keywords: Girlhood; The Red Queen collection; Stereotype.

\section{INTRODUCTION}

The field of girlhood studies has received attention as an academic subject and as a significant issue in popular culture in the last three decades (Crann, 2017). Since this area of research is gaining momentum both in academia and in popular culture, a critical examination of different girl characters in the New York Times Best Selling series can prove rewarding in the study of culture and literature. Therefore, this paper undertakes to examine the way girlhood is constructed by different social and cultural factors in the diegetic world of The Red Queen collection by Victoria Aveyard. Rodgers (2016) maintained that social class has a large role in defining a modern girl. Aveyard's Mare Borrow, as the young protagonist from the working class (Reds), is obsessed with overcoming the limits of her social class. The Red Queen series blatantly upholds a constructionist worldview, which can be a double-edged sword for characters who seek change. Mare's identity for example, is shaped by her blood color, which allots her an inferior position in the world ruled by Silvers. She is thus constructed by external factors, which determine her worldliness but she can also revolutionize the order of society and construct new versions of identity.

This study intended to assess the impact of place on girlhood in The Red Queen collection and examine how girlhood is constructed by geographical, sociological and psychological factors. To frame the argument, different girlhood discourses such as Girl Power, Reviving Ophelia, Girl Effect and \#LIKEAGIRL are viewed to trace girl stereotypes in The Red Queen series. The Red Queen is a very long novel and its protagonist, Mare Borrow is an active Red young girl who lives in a society where people are labeled by the color of their blood: Reds are deemed inferior and power is in the hands of Silvers. Since she is a Red girl, she is considered as the 'other' and less than human. She cannot be powerful unless she can change her blood color, which is not possible for her. But when she changes into the lightning girl and undergoes a kind of physical alterity, she discovers that she has the power to change society. This metamorphosis paves the way for her to overcome social boundaries in order to help the Reds. In other words, politics of place and the distribution of power are in line with her identity construction.

\section{ONGOING DEBATES ABOUT GIRLHOOD}

Before introducing and analyzing different girl characters of The Red Queen collection, it is necessary to review the main debates about girlhood and briefly introduce girlhood theories and their underlying presuppositions to see the extent to which they can be empowering for girls in their private and public lives. One of the debates about girlhood revolves around the opposition between the modern type and the traditional type of girl. Gonick (2006) examined the two modes of 
girlhood that emerged in the early 1990s, which she calls "Girl Power" and "Reviving Ophelia". "Reviving Ophelia" is a mode of girlhood inspired by Shakespeare's character Ophelia in Hamlet as the representation of a crisis of girlhood. As Ophelia is considered an obedient, vulnerable, voiceless and hysterical victim, "Reviving Ophelia" represents moral and social concerns about girls. Although the "Reviving Ophelia" model emerged in the 1990s, it reiterates traditional attitudes towards the discourse of girlhood. In contrast to "Girl Power" and Neoliberal theories, "Reviving Ophelia" does not leave ample space for self-esteem. On the other hand, "Girl Power" as the name indicates, is linked with self-esteem, self-invention, self-determination and individual effort (Gonick, 2006). "Girl Power" celebrates the industrious individual who does her best to achieve her set goals, which is the underlying basis of the self-help culture. Highlighting the self-help culture can result in the enhancement of one's self-esteem. Those critics who argue for the modern type have put forth the theory of Girl Power, and the more traditionally oriented debaters have argued for Reviving Ophelia.

The Riot Grrrl movement coined the term "Girl Power" in early 1990s but the British punk group, the Spice Girls adapted the term in 1996 and "redirected the representation of girlhood from a strong, proactive, smart heroine to a worshiper of feminine beauty and heterosexuality" (Bae, 2011, p. 28). Girl Power was put in circulation to promote and encourage the empowerment, confidence and strength of young women; the discourse was embraced by Hollywood, TV shows, clothing advertisements, videogames and self-help books (Brown, 2011); however, it has been criticized for the "aesthetically oriented consumerism" it embodies. The discourse of Girl Power, Bae (2011) argues, is used frequently in popular media "as a marketing strategy" by establishing a specific style and fashion for the girl who is white and urban.

The Nike Foundation created the Girl Effect movement in 2008, which developed into a non-profit foundation in 2015. This foundation initially encouraged people all over the world to reconsider the role of girls in the development of society. This foundation holds that if girls are given support, they can leave a significant impact on the world. The purpose of this foundation is to end poverty on a global scale by providing for the girls for they, if empowered, could change this world into a better place to live in. This organization mongered a serious debate among commentators who were concerned about girls and women and their roles in the public and private domains. The Girl Effect can be taken as a discourse about girlhood which is deeply scrutinized by Hershey
(2015), who claimed that Girl Effect highlights ideas of agency, strengthening, and development through stages of girl-oriented social correspondences. Hershey (2015) believed that by making adolescent girls, their voices, and their viewpoints progressively obvious inside their networks, they will gain more prominent agency and authority over their own lives. In fact, this idea underscores the importance of higher visibility for girls in the social context, through which they can oppose marginality and gain agency. Despite its popularity, Girl Effect has been criticized for some of the ideologies that it masks. Koffman and Gill (2013), for example, have discussed the emergence and popularity of Girl Effect in the aftermath of 9/11 and after the American invasion of Afghanistan and Iraq. They maintain that when the western forces wanted to withdraw from Afghanistan, there were concerns that girls and women in Afghanistan would be targeted by Taliban again and would lose whatever they gained through the American interventionist policy during the war, therefore white girls from the global north should come forth to play the role of savior for their victimized sisters. The superiority of girls from the global north, in contrast to the assumed wretchedness of girls from the global south underpins the missionary agenda of Girl Effect.

Girl Effect in many ways works in tandem with the discourse of Girl Power in that they both emphasize the strength and self-confidence of girls, and both harbor an undercurrent of racism and colonialism. The Girl Power represented in popular media heroizes the white confident girl who fashions her style and boldly expresses her sexuality. The white, urban privileged girl, who is proud of her girlhood and liberally embraces her sexual autonomy, and the absence or the under-representation of girls of color in the discourse of girl power, hint at the racism inherent in the seemingly aesthetic apolitical agenda of the Girl Power. The binary of the White Girl and the NonWhite Girl which is promoted by Girl Power, finds an echo in another binary constituted by Girl Effect: the White girl/savior from the global north and the oppressed women of the global south. The unequal power relation between white and non-white girls seems to be the point at which Girl Effect and Girl Power intersect. This unequal power relation leads to a missionary configuration of sisterhood according to which it is the moral responsibility of the white girl to save the non-white girls suffering miserably in the developing countries. The powerful white girl very often regulates the oppressed girls into different forms of otherness in order to play the role of the autonomous, benevolent savior. Aveyard depicts a range of girl characters that represent different forms of alterity. She sometimes deconstructs and sometimes reinforces 
stereotypes of Girlhood in The Red Queen collection. The binary oppositions are systematized around the dichotomy of redness as the underprivileged race/class, and silverness as the privileged race/class. Inside the category of redness and silverness however, there are girls that defy the tight outlines of the position to which they have been relegated. The protagonist for example is non-silver girl has a unique ability entitles to the Silver class. A silver girl defies cisnormativity, and her positionality within the silver class depends upon the way she configures her sexual tendency. The Red Queen collection is examined in this paper to see how Aveyard positions her girl characters in relation to different veins of girlhood.

Girl Effect, with its Universalist agenda and despite the empowering mission it purports to be undertaking, has been subject to critical scrutiny. Bent (2013), for example, challenged and re-examined Girl Effect and argued that at its core, lies the premise that Western girls are the rescuers of Third World girls. Thus Third World girls are reduced to passive victims in need of Western saviors. The empowering mission, therefore, embodies a colonial perspective based on a privileged/ underprivileged dichotomy that labels Third World girls as "other" in opposition to Western girls, who are considered as "us" (Bent, 2013). From this perspective, "Reviving Ophelia" and "girls-at-risk" are stereotypes of Third World girls, while Girl Power is the trademark of First World girls. This hegemonic point of view can hardly leave any space for Third World girls' selfesteem and agency. They are considered as passive and vulnerable females who do not experience self-autonomy. Although one can rate Girl Effect as a version of feminist sisterhood, from Bent's perspective, it rather resembles a hegemonic systematization underscoring the social, political, and cultural vulnerability of Third world girls.

Besides the theory of American Girl highlights the agency of Western girls as well. Schalk (2016) studied the issue of American Girl. Schalk (2016) maintained that American Girl characteristics include being brave, unique, doing the best thing she can, speaking up for what she believes in, longing to improve the world, and so on. The eye-catching point is that these characteristics are particular to United States' girls, not the girls from other places of the world. The concept of American Girl is the issue of national identity which belongs to natural-born citizens of the United States. Schalk (2016) revealed that American Girl is an explanatory representation of rhetoric empowerment combined with the concept of national identity.

There are some assessments of American Girl dolls, since the historical narratives recreate historical elements. Acosta-Alzurn found that American Girl is a site that revives customary ideas of womanliness and the attempt to strengthen the race and class orders through its representational methodologies (cited in Medina, 2012). Medina (2012) argued that despite the fact that American Girl narratives fortify attitudes of multicultural and classless American history, at the same time the company duplicates ethnic and classrelated hierarchies. She proceeded that American Girl narratives eternalize global inequalities through the credit they give to the labor of Third World women and children who produce the American Girl dolls, dress, and embellishments for socially privileged purchasers in the United States.

Social media is used as a means of empowerment promoting the concept of self-esteem and encouraging girls to practice self-love. According to the https://campaignlive.co.uk Internet Report presented by Leo Burnett, \#LIKEAGIRL\# used to be a phrase with negative connotations that was used as an insult and therefore had a highly destructive impact on girls' selfconfidence. However, today, there is an attempt by the \#LIKEAGIRL\# campaign to alter its negative meaning through social media. Millions of girls around the world share their activities through social media and use \#LIKEAGIRL\# with positive connotations. For instance, girls use \#LIKEAGIRL\# for such activities as climbing, playing volleyball, fighting, calculating, shooting etc. (Burnett, 2015, 00:00:00 - 00:01:32). The passive consumers of a defined culture have thus metamorphosed into active generators of a new identity in social media. Predefined gender roles are perhaps the most serious obstacles for the new generations who inhabit a world constructed by do's and don'ts that are incompatible with their needs. Gender norms that socialize girls so they take domesticity, matrimony and motherhood as their proper roles, might block the way to independence and selfautonomy. Therefore, \#LIKEAGIRL\# can help social media users resist gender stereotypes, offer new versions of girl identity, and make their new identity visible to the world.

Girl Up is a newly established campaign which underscores "sisterhood". According to Koffman, Orgad and Gill (2015), Girl Up is a campaign that was founded by Washington D. C. based Unite Nations Foundation and its proclaimed point is to start a grassroots development among American girls to give assistance to their Southern sisters through online appeals, alertness raising and girl gatherings, often by the supporting of celebrities. Koffman Orgad and Gill (2015) presented the example of Ivanka Trump who made a Girl Up bracelets part of her gems line to manifest a similar conflating utilization and care; and 
to crumble Northern and Southern girls into an apparently identical "We". One of Trump's recommendations is that girls purchase the bracelets as the graduation present for a companion or a relative, so that the returns of the bracelets will be contributed to the Southern girls' education.

In comparison to Girl Effect, Girl Up stresses sisterhood as its major goal. However, the key term in the Girl Effect is self-agency in a way that it is monopolized to the Western girls. Girl Effect's hegemonic perspective overweighs its stress on sisterhood. However, both highlight the role and the agency of the privileged savior, one through the concept of "sisterhood", the other through a colonial hegemonic perspective. They do not address the selfsubjectivity of the Third World girls, instead they insist on the vulnerable image of the Third World girls whose voices are not taken into account.

\section{GIRL STEREOTYPES IN THE RED QUEEN COLLECTION}

Girlhood is not depicted evenly in The Red Queen collection, but rather through the different characters and their ethnicities, social classes and ideologies. From this perspective, depiction of girlhood in The Red Queen can remind us of Rodger (2016) who, when defining girlhood, argued that being a girl changes across time and circumstances. Being the other is not unique to the Red race in The Red Queen collection. To see how girlhood is depicted in this collection, it is necessary to see whether the characters are 'at-risk' girls or 'can-do' girls. By 'at-risk' girls, the researchers mean Red girls who are born into a place where the social, economic and political contexts have intensified their vulnerability and otherness. By 'can-do' girls, the researchers mean empowered girls as defined by the discourses of Girl Power and Girl Effect. Robards and Bennett (2013) referred to the World Health Organization's definition of 'adolescent' as individuals aged between 10-19 years. The authors of this essay have followed their suit in our selection of adolescent female characters in the collection. Although there are outstanding female characters in the series such as Farley, this study is limited to characters aged between 10-19 years; therefore, the researchers will study girlhood stereotypes represented by Mare, Gisa, Cameron, Evangeline and Iris in The Red Queen collection.

\section{DEPTICTION OF "AT-RISK" GIRLS IN THE RED QUEEN COLLECTION}

Mare is an 18-year-old Red girl who possesses the supernatural ability of generating and controlling electricity. In the diegetic world of the novel, only Silvers have supernatural power, which makes Mare a Red anomaly. She is called the 'lightning girl' because of her atypical power. Mare experiences otherness on different levels. As far as the power structure of the surrounding society is concerned, she is an underprivileged Red with no access to power and rank, and the best she can hope for is to be exempted from conscription by finding a subordinate job in the palace inhabited by the Silvers. She therefore has to claw her way to the upper echelons of her society in order to survive. Red and scarlet are metaphors of the working class on the brink of revolution, while silver represents aristocracy, royalty and power. The colored binary, apart from its classist connotations, can also be a reflection of racist biases. Mare also enjoys a supernatural power which was formerly supposed to be an exclusive silver asset, so she can be considered a hybrid species living in a society where the rigid line between Reds and Silvers should not be blurred or crossed. She experiences alterity on the levels of class, race and body due to her genetic mutation, and hence, defies a simple definition.

Skourtes (2015) in her study of underprivileged urban populations noted that when social class intersects with gender and youth culture, the working class girl emerges as a problem. Classification, she maintains, in terms of social status, gender or race is a strategy used to make the working class people, girls (females) or blacks as unvalued. These groups, which are considered as 'others' in society, are treated by the hegemonic power in such a way as to feel less than human and ashamed of what they are. In her discussion about working class girls, Skourtes (2015) stated that "The girls recognize that they are born into an unvalued place and that in order to be valued they must separate from that place" (p. 110). Skourtes (2015) suggested that working class girls need a culture of self-improvement to gain recognition, value and legitimacy. She maintains that although some girls separate from their home to leave their past behind, some do not give up their home culture completely. This study indicates that gender, class lines, racial inequality, and politics of classification in general operate as a system to stigmatize the 'other' who can be a female, a member of the working class, or black. What Skourtes (2015) said about the intersection of race, class and gender and the way they can work together to alienate an individual standing right in the middle of the intersection, finds its echo in Mare's whereabouts in The Red Queen collection. From a social perspective, Mare is an 'atrisk' girl because of the social categorizations and forces of the environment in which she has to live. Her family is dependent on her sister's sewing career, so she should be subservient to the Silver rule, and in 
order to save her friend she turns to illegal underground activities that aggravate her own and her family's already difficult situation. Classist discriminations against Reds spurn Mare to find an alternative that would help her achieve self-improvement. She recognizes that she has a problem to solve and the problem is her subalternity.

From the very beginning, Mare knew that she was born into an unvalued place where Reds are marginalized. In chapter seventeen of the Glass Sword, Mare asserted that "I have been running for so long. Since before all this even started, even back in the Stilts, I was a runner. Avoiding my family, my fate, anything I didn't want to feel" (Aveyard, 2016, p. 249). As a result, she comes to the decision that she must leave Stilts. Mare separates from her home and leaves her past behind, in order to generate the culture of self-improvement. Getting empowered would help her gain recognition and legitimacy as a Red girl in a Silver-dominated society. She is not associated with the framework of family and domesticity; she is more suited to leadership. Mare challenges the social, cultural and political categorizations which define who qualifies as valuable and who does not qualify as a legitimate citizen.

In many girlhood discourses, such as Girl Effect, Girl up and American Girl, girl stereotypes are categorized by a hegemonic colonial division into 'at-risk' girls and 'can-do' girls. From this stand point, 'at-risk' girls do not have agency because they are vulnerable due to the social, economic and political context of the place they were born into, and in order to enhance their lives' qualities, they are in need of 'can-do' girls, and particularly Western-White-Middle-class girls. Thus, gaining voice is monopolized to the group of girls who are in advantage over the other group of girls. But, in The Red Queen collection Aveyard does not fully yield to this categorization and offers other alternatives.

Mare can be inserted into the 'at-risk' group, for she was born into a place where social, political and economic circumstances fortify her vulnerability and social otherness. She was born as a Red in Stilts, where Reds were either forced to hard labor or conscripted into the Silver's war by the age of eighteen. Mare however cannot be accommodated in such stereotypical pigeonholes. Although being Red defines people's social class in The Red Queen collection, and despite the fact that this is an indisputable law carved in stone, Mare crosses the boundaries of the 'at risk group' by gaining a voice of her own through her physical alterity and joining the Scarlet Guard, thus saving her own life and those of the oppressed Reds. Thus, being 'at-risk' is not in conflict with being a 'cando' girl, for she is both. Mare's physical othering is not a one-dimensional alterity, but rather a stage of development and an experience of self-alienation for her. Initially, her Electrokinesis ability does not give her a voice. On the contrary, it alienates her from herself and her identity as a Red girl by conferring her with a fraud Silver identity. She gains a voice when she joins the Scarlet Guard; only then can her supernatural ability pave the way for her empowerment.

According to Bettis and Adams (2012), the standards of femininity have changed so much that girls can enter and tread upon masculine grounds. The Red Queen collection can be taken as an example in which female protagonists are portrayed as active individuals who do not need a male character to fulfill their life desires; this type of femininity and girlhood is incarnation of the Girl Power theory. Mare enters the masculine sphere, for she is active and independent, achievementoriented, and a warrior. Not only is she not a passive princess in need of a male hero to save and protect her, but she herself is the one who saves the prince of Norta and her friend, Kilorn. Not only Mare, but also Cameron, Iris, and Evangeline's characterizations are in line with the norms of Girl Power, for they are all warriors who are ready to take risks.

In her character descriptions, Aveyard seems to be challenging stereotypical images of adolescent girls. In Mare's case, conventional traits that are usually attributed to girls such as purity, morality, romance and beauty are either reversed or moderated. She is not a pure angel, but an adolescent who makes mistakes or does the wrong thing sometimes. Unlike traditional depictions of encaged virgin girls associated with domesticity and passivity, Mare is identified with independence and empowerment. As far as her physicality is concerned, her ability as the lightning girl, rather than her beauty or her appearance, is highlighted throughout the novel. She is depicted as a short and ordinary girl with brown eyes, hair and skin. However, in contrast to Mare, her sister is portrayed as appealing and charming in appearance but docile and unassertive in behavior.

Aveyard offers two opposing versions of girlhood in the Barrow family. Gisa, Mare's younger sister, is a 15 year old Red who also experiences social otherness. Moruzi and Smith (2014) suggested that adolescent girls are regularly associated with the framework of family, and this is attributable to the traditional relationship between femininity and domesticity in which an adolescent girl was required to advance from the roles of daughter and sister to those of spouse and mother. Accordingly, Gisa's world is limited to family interactions and the traditional role of a daughter, and is thus characterized by domesticity and traditional 
roles, while Mare does not align with this formula of girlhood and never makes this transition. Gisa therefore seems to be Mare's traditional alter-ego.

As opposed to Mare, Gisa is a passive Red who was born as a member of working class and continues to be a Red, working class girl. She is happy to be a tailor and make clothes for Silver houses, and is satisfied with receiving her family's compliments and being known as an angel at home. Unlike Mare, Gisa does not leave her home and past behind. According to Currie and Kelly, there is a tension between traditional and modern images of girlhood, because the "good girl" who spends her girlhood doing caretaking and supporting jobs rivals the new notion of Girl Power (cited in Ivashkevich, 2011). Gisa is not an achievement-oriented individual and represents an 'atrisk' girl who is in need of a savior. In Mare's words in The War Storm, "My sister is not a violent girl, better suited to a needle than a knife" (Aveyard, 2018, p. 514). Mare is a fighter who resists and challenges her fate as a Red, while Gisa embraces her defined fate. Therefore, Gisa is an instance of the Ophelia type due to her vulnerability, voicelessness, and obedience. By way of comparison, Mare is the representative of the empowered type of girl because of her subjectivity, self-esteem, and her adherence to the self-help culture. Thus, The Red Queen series accommodates both the new type as well as the conventional type of girlhood.

In the imaginary land of Norta, there is a town called New Town known as Gray Town, for there are many factories, where Reds are forced to work. They do everything for Silvers and keep their power running, but they gain nothing in return but smoke. New Town is one of the most horrible sites in Norta and even worse than Stilts, where Mare was born. The Reds of New Town cannot even be conscripted, for living and working in Gray Town is even worse than conscription. The greenwardens of Norta grew barrier trees in front of New Town to keep the pollution away from Silver sites.

Cameron is a 15 year old Newblood- Red blood born people with superhuman abilities- who used to be a techie in New Town and possesses the silencing ability. She and her twin brother Morrey, as the members of the Red society, were oppressed for many years by the Silvers. By the force of environment, they were born in New Town and-like their parents and other Reds born in New Town-they are forced to work in factories. Working and living in New Town is the only way of life that people of Gray Town know. Working class Reds are called "techies" in Gray Town and Archeon and everyone is coded with a number. This industrialized site can be considered as a colony whose resources are exploited by the Silvers. Techies' otherness, therefore, can be categorized as a colonial alterity which comes about as a result of the denial of the identity of the colonized. Al-Saidi (2014) maintained that "The other by definition lacks identity, propriety, purity, literality" (p. 95). All the people of New Town have a code tattooed on their necks which is their identity. In chapter eighteen of the War Storm, Cameron shows Mare her tattooed neck, which was marked as "NT-ARSM-188907" (Aveyard, 2018, p. 301) and stated that "Every one of us is a number up there" (Aveyard, 2018, p. 301). In accordance with AlSaidi's post-colonial perspective on otherness, Cameron, her twin brother, her parents, and every other Red living in New Town is marginalized as the other because they lack an identity of their own. Since they are different from the Silvers, they are imperfect and hence dehumanized.

Cameron was forced to join the Scarlet Guard but gains two benefits from this: she learned to control her power and saved her brother from Corros prison. Like Mare, Cameron's ability is a sort of lethal power, and her lethality can oftentimes overtake that of Mare. She finds Mare's approach violent and egocentric and is firmly of the opinion that Mare favors Newbloods over Reds to make them fight her war. Once, Mare enforced Cameron to employ her ability to kill and at their first encounter Cameron was forced to join the Scarlet Guard. These occurrences shape a negative image of Mare and the Scarlet Guard in her mind. Thus emotionally disconnected from Mare's cause, Cameron sets her goals on a very individualist, and not an altruistic, path. When she succeeds in saving her twin brother, she went far away with him and escaped danger. Cameron was an 'at-risk' girl due to her social, economic, racial and political vulnerability. However, before recognizing her ability, and despite the fact that she was an 'at-risk' girl, she was not a passive victim. She did not embrace the Silver's sociopolitical constructions and, like Mare, recognized that she was born into an unvalued place and therefore left her home and her past behind and was imprisoned. However, she did not give up and managed to escape from Corros prison. Possessing a preternatural ability and allying with the Scarlet Guard enhanced her power and voice. She represents the discourse of Girl Power and reverses the stereotype of the damsel in distress by playing the role of a savior for her twin brother who was in trouble and in need of help.

\section{DEPICTION OF “CAN-DO" GIRLS IN THE RED QUEEN COLLECTION}

Evangeline is a 19 year old Silver princess who has the ability of metal manipulation. She is considered as an 
"other" due to her gender and homosexuality. As stated previously regarding the power of environment and hereditary traits, Evangeline was born as a princess and her life path should lead her into queenhood. Social constructions have placed her in a defined position in relation to her social class and her gender. Thus, Silvers as high-status groups are not immune to power rivalries.

The classification and hierarchization of different classes seem to be a motif in the collection. Citizens are not only pigeonholed in terms of social class, race and gender, but they are also regulated hierarchically in each category. In the imaginary land of Norta and Lakelands, for example, people are categorized by the color of their skin, which identifies their social classes as well. However, Silvers themselves are categorized by their Houses and their abilities. There are many Silver Houses, such as House Arven, House Iral, House Macanthos, House Rhambos, and so forth. There is a hierarchal system ruling Silver Houses: for instance, Julian and Queen Corian are from House Jacos, a Silver family lacking in credit compared to other Silver Houses because of the casualties they suffered in the Lakelander war and the dwindling number of its members. Queenstrail perfectly illustrates the rivalry between Silver Houses to practice power over other houses and consists in a traditional convention in Norta and stage for ladies of the high Houses of Silvers to present themselves to the prince. The future queen would be the one who presents her ability better than the other candidates.

To all appearances, Queenstrail may be interpreted as a competition based upon patriarchal standards, for it is a harsh contest between girls to attract the prince's attention. We might be reminded of the prince's ball in the story of Cinderella; but unlike Cinderella, who charms the prince through dance, the candidates in Queenstrail further demonstrate their qualification. Arin Barry suggests that Victoria Aveyard changed the narrative in a way that the candidates are judged based on their abilities, not their appearance beauty. It is a stage for Silver Girls to compete based on their abilities but, like in the tale of Cinderella, the competition results in hostility among girls who wish to become the queen. In chapter six of The Red Queen, Mare commented on the Queenstrail and notes that "One of those girls gets to be the next queen, and they're slapping each other silly for the chance" (Aveyard, 2015 , p. 56). Queenstrail, as a ground for hostility among girls and their Houses to gain the prince's attention, represents a liminal space and a contact zone between modernity and tradition by encouraging girls to empower themselves on the one hand, and pushing them to extremes of competition to win the status of the queen on the other.
Evangeline stands out through her rebellion, empowerment and risk taking which are, as Heatwole (2016) revealed, new modes of girlhood depiction. Her character is completely and entirely in conflict with old stereotypes associated with vulnerability, marriageability and romanticism. Evangeline is the girl type propagated by the discourse of Girl Effect. Hershey (2015) claims that the discourse of Girl Effect upholds the hypothesis of progress in order to address and challenge social norms that keep girls within male centric power structures. Although Evangeline was interested in a Silver girl, Elane Haven, she was pushed by her father, Volo Samos, to get engaged to $\mathrm{Cal}$ Calore in order to unite Rift and Norta through heterosexual marriage. To maintain her status in the monarchic system, she had no other choice but marry a man and become a queen. She stated in "the Iron Heart" in the Broken Throne:

Even a Silver child knows that. It's painfully obvious. Everyone knows the laws of succession in my old country, or at least what they were. Men first, and when none are left, the crown passes to a daughter. A person born to be a pawn becomes the ruler of the board. (Aveyard, 2019, chapter. 1)

From this perspective, she is the second sex who is considered as the "other" in comparison to her brother, who is regarded as legitimate and more deserving. Although she was voiceless for a long time, she ultimately grows beyond prohibitive social codes and challenged gender-oriented desires through her individual effort and resistance. After all, she swore her allegiance to the Free Republic of Montfort to live freely.

Although Evangeline is more aligned with the discourses of Girl Power and Girl Effect, the idea that 'can-do' girls are the saviors of 'at-risk' girls, which is a fundamental basis of the Girl Effect movement, seems to have been eliminated from Evangeline's depiction. She is represented as a self-reliant girl who obtains a voice of her own but not the savior of 'at-risk' Red girls. Only once, in the King's Cage, Evangeline saved Mare, not for the sake of 'sisterhood' but for her own brother's benefit because Ptolemus had killed Shade. By saving Mare, Evangeline was assured that Mare would not carry out her plan to murder Ptolemus and avenge Shade, so it was a mutually profitable movefor Mare and Evangeline.

Evangeline's homosexual desires lead to her otherness. Aveyard underemphasizes dominant biological sexual propensities and highlights a liberal feminist perspective on "choice" for girls through Evangeline. Towards the end of the War Storm, Evangeline decides to run away with Elane to Montfort where, as she stated, 
people are "allowed to be who they are" (Aveyard, 2018, p. 479). Montfort is presented as Utopia in contrast to Norta, which is portrayed as a dystopia. Montfort is an ideal republic where Silvers and Reds are considered equal. This implies that the significance of Montfort is its function as a mirror of Norta. In the republic of Montfort, a Red homosexual man, Dane Davidson, is premier and there is no Silver superiority, nor is there a Silver/ Red or heterosexual/ homosexual dichotomy. Race and color of blood do not define social status there.

Iris is a Silver princess who is regarded as the "other" due to her gender. She was sold to Norta by will of her father, whose objective was to unite Norta and Lakelands. Iris verbalizes her anguish in the War Storm, when she said "how many nights did I spend alone in Whitefire Palace, awake and telling myself I felt no remorse? No anger at having been sold like a pet or an acre of land? It was a lie then and a lie now" (Aveyard, 2018, p. 65). The marriage was an agreement between the King of Norta and the King of Lakelands to end the war. Her individualism was denied and she was dealt with like an object. To change her defined fate, she betrays Maven's kingdom when she gets a chance and gains a voice of her own as an individual. Therefore, resistance to social norms is not limited to the heroine of the novel and the rebellious Red people who were oppressed for years. Evangeline and Iris, who are from High Houses of Silvers, do not remain faithful to their fathers' rules.

Stereotyping girlhood has a lot to do with gender alterity. Before the Feminist, Post-feminist, and Neoliberal eras, the depiction of female characters in texts and media conformed with patriarchal frameworks and standards because women were considered as the second sex and the patriarchal system had been operating as the system of power which had the power to shape and control female identity to an extent. Nonetheless, as Paule (2017) revealed, there is a "new mode of highly visible girlhood" in post-feminist era media and texts (p. xiii). In line with the "new mode of highly visible girlhood", The Red Queen depicts a highly visible girlhood and, by not attributing unwanted human characteristics into its female characters, it grants them voice and legitimacy.

From a colonial perspective, The Red Queen is completely and entirely in opposition with the doctrine of the Girl Effect movement, because the latter ignores the agency and subjectivity of 'at-risk', black, lowerclass and Third World girls. The Girl Effect discourse highlights the agency and subjectivity of the Western White middle-class girls who are considered the saviors of "at-risk-girls" (Bent, 2013). If we invoke this theory, then we should expect a Silver girl to be the savior of a passive Red girl. In The Red Queen, 'girlsat-risk' embark on challenging social, cultural and political frameworks in order to gain their own voice and become prototypes of girl power.

By spotlighting the endeavors of Red girls, Silver homosexual girls and Silver girls in loveless marriages, The Red Queen collection challenges many girlhood discourses, since many of them, such as the American Girl, Girl Power and Girl Effect directly or indirectly address Western White Middle-class girls. Although Red girls were "at-risk", hierarchal social structures do not stop them from taking significant actions. In spite of the social injustices and gender and ethnic discriminations that limit Red girls, they do not yield their chances of freedom but rather seek self-development and empowerment. In a corrupt oppressive system, there might be no other way than using violence to fight back against injustice. However, it does not mean that victims are doomed to stand as victims; at least such is the case in the diegetic world of The Red Queen collection. Victims turn to heroes/ heroines, albeit at a substantial price.

As it is seen from the life paths taken by the girl characters in the collection, victim mentality is not an indissoluble matter; therefore, dichotomizing girls as victim and heroin does not count in the series because girls can develop from victims to powerful queens. In such discourses as Girl Effect, labeling particular groups of girls as victims, and labeling other groups as heroines is neither all-inclusive nor functional. Typically, being a victim and being a heroine are closely intertwined in Aveyard's The Red Queen collection. For instance, being a heroine is contingent upon being a victim. To gain a voice, one might recognize the imbalanced laws and ideologies, which hold her/him in position of powerlessness. Through recognition, the other who is a victim can grow, get empowered, gain a voice and even turn into a heroine. Aveyard gives voice to the others from both the Silver class/race and Red class/race. Aveyard portrays her 'at-risk' girls as the saviors of their own lives, so no girl in power is needed to save them. The girl characters that Aveyard presents are very much in line with Crann's (2017) account of Girl Power marked by being autonomous, ambitious, victorious and resilient.

Driscoll's argument that "local specificity produces and evaluates styles of girlhood and distinctions between types of girl" (cited in Mitchell and Renstchler, 2016, p. 1), is rejected in The Red Queen collection for it avoids categorizing girls' stereotypes based on their geographical and social places. Categorizing individuals based on their differences and 
social and geographical places results in shaping the binary opposition of Self/Other. Modern girlhood, as Rodgers (2013) noted, is marked by heroism, genius and community, regardless of differences in social class, age or geographical location. The stereotypes that The Red Queen collection puts forth are closely in line with Beth Rodgers's definition of the modern girl, because Mare, Cameron, Evangeline and Iris are marked by their heroic actions, creativity and their concern with communal values, irrespective of their differences in social class, age, ethnic and geographical place.

\section{CONCLUSION}

There are various discourses in the domain of girlhood studies. Girl Power, Reviving Ophelia, Girl Effect, \#LIKAEGIRL and Girl Up have been studied and discussed in the present article. Reviving Ophelia and Girl Power are two opposing ways of defining girlhood, which promote very different girl stereotypes. While Girl Power is associated with subjectivity, self-esteem and self-help culture, Reviving Ophelia is characterized with vulnerability and being voiceless. These two concepts contradict each other regarding the fact that the Reviving Ophelia model conforms to traditional social and cultural frameworks while the Girl Power discourse is more in line with modern cultural and social standards. While Gisa conforms to traditional codes of girlhood regarding her characterization as voiceless, obedient and vulnerable, Mare, Cameron, Evangeline and Iris are the representatives of the Girl Power discourse, for they gain a voice of their own through self-agency, ambition and self-help culture. Therefore, two opposing depictions of girlhood are presented in The Red Queen collection: Reviving Ophelia and Girl Power.

The Girl Effect movement provides two opposing stereotypes in its essence. This implies that it addresses White Western girls as self-reliant and saviors and marks Third World girls as victims in need of saviors. By shaping a colonial binary opposition of 'can-dogirls' and 'at-risk-girls', the two discourses demonstrate a hegemonic perspective of the privileged. 'Atrisk' girls are considered as the "other" in comparison to 'can-do' girls, who are regarded as the Self from a post-colonial perspective.

From this point of view, the Reviving Ophelia and 'atrisk' girls of the Girl Effect movement fall into one categorization, which underscores vulnerability and voicelessness. The Girl Up discourse addresses American girls to assist their Southern sisters with the slogan of sisterhood. It is somehow identical to Girl Effect theory, in that its addressee is the privileged and it highlights the vulnerable image of the Third World girl who leaves no space for underprivileged girls to exercise self-esteem and agency.

Mare and Cameron challenge the Girl Effect's doctrine which upholds vulnerable images of 'at-risk' girls and reduces them to voiceless victims. Although they are examples of 'at-risk' girls as regards their ethnic and social class, they are not depicted as voiceless victims but actually develop in the course of the series. Instead of highlighting the vulnerable image of the other, The Red Queen underscores the notion of resistance. In the Girl Effect discourse, there is a sort of psychological process of internalization which seeks to internalize the idea that 'at-risk' girls are born into a valueless place and are supposed to be victims unless a privileged 'cando' girl saves them. Nevertheless, The Red Queen addresses and asks 'at-risk' girls to be the saviors of their own lives by rejecting the over-simplified categorization of heroine/victim. By representing various and opposing girl stereotypes, Aveyard highlights her disapproval of the essentialist configurations of gender identity and sexuality. For instance, by depicting Mare as a warrior and Farley as a commander, she rejects the essential-oriented and patriarchal ideologies which seek to define the borders of female's interests and gender roles. The Red Queen generates its own culture within the domain of girlhood and womanhood, and underscores the idea of choice and responsibility for girls.

In line with the doctrine of Girl Power, liberal and neoliberal feminism, The Red Queen collection draws attention to self-help culture. Despite the fact that Aveyard gives voice to others who are excluded from the position of power and highlights the notion of resistance, the authors did not consider the collection as a sort of idealistic novel, for The Red Queen does not promise total victory to the individual. Mare and the Scarlet Guard's achievements are a sort of altruistic victory rather than individualistic triumph. Although The Red Queen values individual effort and success, it demonstrates that a great price should be paid for great victories. As regards this idea, The Red Queen is more realistic than idealistic. In a broader context and as an altruistic approach, Mare's quest ends in a grand achievement; however, it has a great price for her as an individual, for she loses her innocence and her brother. Yet, this is not a rare motif, because generally speaking, it is fairly common in literature that the hero/ heroin's quest contributes to an altruistic accomplishment rather than individualistic fulfillment.

Traditional gender roles have faded away in this series. More accurately, the boundary between feminine and masculine gender roles is blurred in the Red Queen 
collection. Being a warrior, or a commander fighting with enemies has frequently been associated with masculinity and has been monopolized to male protagonists in traditional tales. In Aveyard's depiction, these characteristics are attributed to the adolescent heroin and other female characters of the collection.

Aveyard tries to push the boundaries of girlhood by replacing old stereotypical images with more empowering depictions of girl characters. For instance, by depicting Mare as a warrior and Farley as a commander, she rejects essential-oriented and patriarchal paternalistic ideologies that seek to define the borders of female's interests. The Red Queen generates its own culture within the domain of girlhood and womanhood and underscores the idea of choice and responsibility for girls.

\section{REFERENCES}

Al-Saidi, A. (2014). Post-colonialism literature the concept of self and the other in Coetzee's Waiting for Barbarians: An analytical approach. Journal of Language Teaching and Research, 5(1), 95105. https://doi.org/10.4304/jttr.5.1.95-105

Burnett, L. (2015, March 4). Always"\#likeagirl stronger together". [video]. https://www.campaignlive.co.uk/article/always-likeagirl-strongertogether-leo-burnett-london-chicago-toronto/ 1336637

Aveyard, V. (2015). Red Queen. New York: Harper Teen.

Aveyard, V. (2016). Glass sword. New York: Harper Teen.

Aveyard, V. (2017). King's cage. New York: Harper Teen.

Aveyard, V. (2018). War storm. New York: Harper Teen.

Aveyard, V. (2019). Broken throne. London: Orion.

Bae, M. S. (Winter 2011), Interrogating girl power: Girlhood, popular media, and postfeminism. Visual Arts Research, 37(2). 28-40. https://doi. org/10.5406/visuartsrese.37.2.0028

Barry, A. (2018, May 21). Why Victoria Aveyard's portrayal of women in Red Queen matters. http://www.cordatethereader.wordpress.com

Bent, E. (2013). A different girl effect: Producing political girlhoods in the "Inest in Girls" climate. In J. K. Taft, \& S. Kawecka Nenga (Eds.), Youth engagement: The civic-political lives of children and youth (pp. 3-20). Bingley, UK: Emerald.

Bettis, P. J., \& Adams, N. G. (2012). Geographies of girlhood: Identities in-between. New York: Routledge.
Brown, M. (2011). The Sad, the Mad and the Bad: Coexisting discourses of girlhood. Child and Youth Care Forum, 40(2). https://doi.org/10.1007/ s10566-010-9115-5

Crann, S. (2017). Rewriting girlhood: Gendered subjectivities among girls and young women attending a girl's empowerment program in rural Canadian community. [Doctoral dissertation, The University of Guelph]. The Atrium. https://atrium.lib.uoguelph.ca/xmlui/handle/1021 $4 / 10323$

Gonick, M. (2006). Between "girl power" and "reviving Ophelia": Constituting the neoliberal girl subject. NWSA Journal, 18(2), 1-23. https://doi.org/10.1353/nwsa.2006.0031

Heatwole, A. (2016). Disney girlhood: Princess generation and once upon a time. Studies in Humanities, 43(1-2), 1-19.

Hershey, R. (2015). The girl effect movement: Impact of social communications platforms in the empowerment of adolescent girls [Bachelor's thesis, University of Oregon]. UOregon Campus Repository. https://scholarsbank.uoregon.edu/ xmlui/handle/1794/20298

Ivashkevich, O. (2011). Girl power: Postmodern girlhood lived and represented. Visual Arts Research, 37(2), 14-27. https://doi.org/10.5406/ visuartsrese.37.2.0014

Koffman, O., Orgad, S., \& Gill, R. (2015). Girl power and 'selfie humanitarianism'. Continuum: Journal of Media and Cultural Studies, 29(2), 157-168. https://doi.org/10.1080/10304312. 2015.1022948

Koffman, O, Gill, R. (2013). 'The revolution will be led by a 12-year-old girl': Girl power and global biopolitics. Feminist Review 105, 83-102. https://doi.org/10.1057/fr.2013.16

Medina, V. E. (2012). "And that's what I think being an American girl is all about!': Girls' reflections on American girl and contemporary American girlhood. [Doctoral dissertation, University of Missouri]. MOspace Institutional Repository. https://mospace.umsystem.edu/xmlui/handle/10 $355 / 15888$

Mitchell, C., \& Rentschler, C. (2016). Girlhood and the politics of place. New York: Berghahn Books.

Moruzi, K., \& Smith, M. J. (2014). Colonial girlhood in literature, culture and history. New York: Palgrave Macmillan.

Paule, M. (2017). Girlhood, schools, and media: Popular discourses of the achieving girl. New York: Routledge.

Robards, F., \& Bennett, L. (2013). What is adolescence and who are adolescents? In M. Kang, R. S. 
Skinner, L. A. Sanci, \& S. M. Sawyer (Eds.), Youth health and adolescent medicine. East Hawthorne:IP-Communications-Pty-Ltd.

Rodgers, B. (2016). Adolescent girlhood and literary culture at the fin de siecle: Daughters of today. New York: Springer Nature.
Schalk, S. (2016). Albenationalism in American girlhood. Girlhood studies, 9(1), 36-52. https://doi.org/10.3167/ghs.2016.090104

Skourtes, S. (2015). Distrupting the Invisibility of Workimg-Class Girls: Redemption, Value, and the Politics of Recognition. Girlhood Studies, 8(3), 103118. https://doi.org/10.3167/ghs.2015.080309 